\title{
Profil Bayi Rujukan Saat Masuk Rawat Ditinjau dari the STABIE Program
}

\author{
Ema Alasiry \\ Bagian Ilmu Kesehatan Anak, Fakultas Kedokteran Universitas Hasanuddin/RS Dr. Wahidin Sudirohusodo, \\ Makassar
}

\begin{abstract}
Latar belakang. Sugar and safe care, temperature, airway, blood pressure, laboratoratorium work and emotional support (S.T.A.B.L.E) program adalah suatu program/pelatihan kepada para pelaku pelayanan kesehatan untuk menilai dan menstabilkan bayi sakit setelah tindakan resusitasi atau sebelum bayi dirujuk. Dalam program ini, seorang bayi sakit harus terhindar dari kondisi tidak stabil yaitu hipoglikemi, instabilitas suhu (terutama hipotermi), gangguan napas (hipoksia), dan hipoperfusi (syok). Keempat kondisi tersebut sangat erat hubungannya dengan peningkatan risiko kematian bayi baru lahir.

Tujuan. Mengetahui jumlah kasus rujukan rawat dan jenis ketidakstabilan (menurut the STABLE program).

Metode. Penelitian retrospektif, mengambil data dari rekam medis bayi yang dirujuk ke ruang perawatan neonatus RS dr. Wahidin Sudirohusodo Makassar, periode Januari - Desember 2010. Subyek dibagi dalam kelompok bayi dengan kondisi stabil dan tidak stabil menurut the S.T.A.B.L.E program, dan dianalisis dengan SPSS 17.0

Hasil. Terdapat 139 bayi rujukan yang turut dalam penelitian. Sebagian besar bayi rujukan saat masuk rumah sakit berada dalam kondisi tidak stabil (64,7\%). Diagnosis yang tersering menjadi alasan bayi dirujuk adalah infeksi dan gangguan napas, sedangkan kondisi tidak stabil yang paling sering ditemui adalah ketidakstabilan suhu $(38,1 \%)$ terutama hipotermi. Ketidakstabilan lain adalah hipoksi $(36,7 \%)$ diikuti dengan hipoglikemi (5\%), dan hipoperfusi $(1,4 \%)$.

Kesimpulan. Sekitar dua pertiga bayi rujukan berada dalam kondisi tidak stabil saat masuk rawat di rumah sakit dan jenis kondisi tidak stabil yang tersering adalah hipotermi. Sari Pediatri 2011;13(4):235-8.
\end{abstract}

Kata kunci: bayi rujukan, the S.T.A.B.L.E program

\footnotetext{
Alamat korespondensi:

Dr. Ema Alasiry, SpA..Jl Petta Punggawa No. 24, Makassar, Telp: 0411 5279004/ Hp: 0811443641, Fax 0411-590629. E-mail: alasiryema@ yahoo.com
}

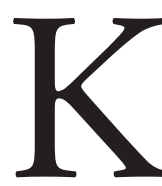

ematian neonatus merupakan komponen utama penyebab angka kematian bayi (infant mortality rate), yaitu angka yang dipakai suatu negara. Dalam Rencana Pembangunan Jangka Menengah Nasional (RPJMN) tahun 2010-2014 salah 
satu sasarannya adalah menurunkan angka kematian bayi (AKB) dari 34 per 1000 kelahiran hidup menjadi 23 per 1000 kelahiran hidup. ${ }^{1}$

Berbagai upaya telah dilakukan pemerintah untuk menurunkan $\mathrm{AKB}$, salah satu diantaranya adalah melalui pelayanan perinatal regional. Sayangnya, upaya ini belum terealisasi dengan baik karena berbagai faktor penghambat antara lain jumlah dan distribusi yang tidak merata dari dokter dan paramedik, keinginan untuk melakukan semua pelayanan tanpa memandang sumber daya dan jenis pelayanan yang diperlukan, takut kehilangan pasien, tidak mengenali masalah yang memerlukan rujukan serta persiapan, dan cara merujuk yang buruk. ${ }^{2}$ Dari berbagai faktor penghambat ini pengalaman dokter dan paramedik yang kurang dalam mengenali masalah pada bayi yang memerlukan rujukan, persiapan, dan cara merujuk. Hal tersebut merupakan faktor yang relatif mudah diintervensi yaitu melalui pelatihan kepada para dokter dan paramedik.

Pelatihan The S.T.A.B.L.E (sugar and safe care, temperature, airway, blood pressure, laboratoratorium work and emotional support) program dilakukan kepada para pelaku pelayanan kesehatan untuk menilai dan menstabilkan bayi sakit setelah tindakan resusitasi atau sebelum bayi dirujuk. Dalam program STABLE, seorang bayi sakit harus terhindar dari kondisi tidak stabil yaitu hipoglikemi, instabilitas suhu (terutama hipotermi), gangguan napas (hipoksi) dan hipoperfusi (syok), serta dilengkapi dengan pemeriksaan laboratorium untuk pemantauan fungsi tubuh dan tunjangan psikologis berupa penyuluhan dan edukasi kepada orang tua. Keempat kondisi yang langsung dapat ditemukan pada bayi rujukan saat masuk rumah sakit yaitu hipoglikemi, instabilitas suhu (terutama hipotermi), gangguan napas (hipoksia), dan hipoperfusi (syok) sangat erat hubungannya dengan peningkatan risiko kematian bayi baru lahir. ${ }^{3}$

Diperlukan penelitian untuk mengetahui jumlah kasus rujukan yang datang dengan kondisi tidak stabil (menurut the stable program) dan jenis ketidakstabilan yang paling dominan pada bayi yang dirujuk. Hasil penelitian dapat digunakan sebagai dasar untuk merencanakan prioritas intervensi selanjutnya.

\section{Metode}

Penelitian retrospektif, mengambil data dari rekam medis bayi yang dirujuk ke Ruang Perawatan neonatus RS dr. Wahidin Sudirohusodo Makassar, pada Januari sampai Desember 2010. Kriteria inklusi adalah semua bayi rujukan usia kurang dari delapan hari yang memiliki data rekam medis lengkap. Kriteria eksklusi adalah bayi dengan kelainan kongenital berat (anensefali, trisomi 13 dan 18). Subyek dibagi dalam kelompok bayi dengan kondisi stabil dan tidak stabil menurut the stable program.

Beberapa karakteristik subyek sebagai data awal penelitian dicatat dari ibu dan bayi. Kondisi tidak stabil (menurut the stable program) yang dimasukkan dalam penelitian ini meliputi hipoglikemi, ketidakstabilan suhu, hipoksia, dan hipoperfusi. Bayi dikategorikan hipoglikemia bila pemeriksaan kadar gula darah sewaktu $<45 \mathrm{mg} /$ dl dengan menggunakan darah perifer pada telapak bayi yang telah dihangatkan dan diperiksa dengan reagent strip (glukose oxidase). ${ }^{4}$ Apabila hasil pengukuran suhu di aksila dengan termometer air raksa selama 5 menit didapatkan suhu tubuh $<36,5^{\circ} \mathrm{C}$ berarti bayi tersebut mengalami hipotermi dan bila suhu tubuh $>37,5^{\circ} \mathrm{C}$ berarti bayi tersebut mengalami demam. ${ }^{5}$ Bayi mengalami gangguan napas (hipoksia) apabila skor Downe $\geq 4$ dan atau saturasi oksigen $<88 \mathrm{~g} \%$ sedangkan hipoperfusi apabila waktu pengisian kembali kapiler $>3$ detik. $^{6}$

Data dimasukkan ke dalam komputer dengan program SPSS 17 dan dianalisis secara deskriptif dengan tampilan frekuensi dan persentase.

\section{Hasil}

Selama periode Januari - Desember 2010 terdapat 139 bayi yang memenuhi kriteria inklusi. Sembilanpuluh bayi cukup bulan dan 49 bayi kurang bulan. Sebaran karakteristik pada kelompok bayi stabil dan tidak stabil saat dirujuk tertera pada Tabel 1.

Analisis statistik memperlihatkan bahwa sebagian besar bayi rujukan saat masuk rumah sakit berada dalam kondisi tidak stabil $(64,7 \%)$ dan tidak ada perbedaan baik rerata usia kehamilan, rerata usia ibu, dan rerata berat badan bayi. Rerata usia bayi saat dirujuk pada kelompok tidak stabil lebih muda artinya bayi-bayi tersebut lebih cepat dirujuk.

Tabel 2 menunjukkan 3 diagnosis utama alasan bayi dirujuk adalah sepsis $(29,5 \%)$, gangguan napas $(25,2 \%)$, dan kelainan bedah $(20 \%)$. Walaupun alasan merujuk karena bayi berat lahir rendah (BBLR) 
Tabel 1. Karakteristik subjek

\begin{tabular}{lcc}
\hline Karakteristik subjek & $\begin{array}{c}\text { Stabil } \\
(\mathrm{n}=43)\end{array}$ & $\begin{array}{c}\text { Tidak stabil } \\
(\mathrm{n}=96)\end{array}$ \\
\hline Jenis kelamin & & \\
$\quad$ Laki-laki & 26 & 63 \\
$\quad$ Perempuan & 17 & 33 \\
Rerata usia kehamilan (minggu) & 37,58 & 36,64 \\
Rerata usia ibu (tahun) & 27,77 & 27,35 \\
Rerata usia bayi saat dirujuk (jam) & 92 & 59 \\
Rerata BB bayi(gram) & 2635 & 2517 \\
\hline
\end{tabular}

Tabel 2. Distribusi diagnosis utama alasan bayi dirujuk

\begin{tabular}{lc}
\hline Diagnosis & $\begin{array}{c}\text { Jumlah bayi, } \mathrm{n}(\%) \\
\mathrm{n}=139\end{array}$ \\
\hline Sepsis & $41(29,5)$ \\
Gangguan napas & $35(25,2)$ \\
Kelainan bedah & $29(20)$ \\
Kejang & $13(9,4)$ \\
Bayi berat lahir rendah & $10(7,2)$ \\
Ikterus neonatorum & $3(2,2)$ \\
Lain-lain & $8(5,8)$ \\
\hline
\end{tabular}

Tabel 3. Distribusi kondisi tidak stabil saat masuk rawat

\begin{tabular}{lccc}
\hline $\begin{array}{l}\text { Kondisi } \\
\text { tidak stabil }\end{array}$ & $\begin{array}{c}\text { Bayi cukup } \\
\text { bulan }(\mathrm{n}, \%) \\
\mathrm{n}=90\end{array}$ & $\begin{array}{c}\text { Bayi kurang } \\
\text { bulan }(\mathrm{n}, \%) \\
\mathrm{n}=49\end{array}$ & $\begin{array}{c}\text { Jumlah } \\
(\mathrm{n}, \%) \\
\mathrm{n}=139\end{array}$ \\
\hline Hipoglikemi & $2(2,2)$ & $5(10,2)$ & $7(5,0)$ \\
Hipo/hipertermi & $28(31,1)$ & $25(51,0)$ & $53(38,1)$ \\
Hipoksi & $28(31,1)$ & $23(46,9)$ & $51(36,7)$ \\
Hipoperfusi & $2(2,2)$ & $0(0)$ & $2(1,4)$ \\
\hline
\end{tabular}

tertera hanya $7,2 \%$, namun secara keseluruhan BBLR meliputi $35,2 \%$ dari bayi yang dirujuk.

Pada Tabel 3 sebaran kondisi tidak stabil terbanyak adalah ketidakstabilan suhu $(38,1 \%)$ terutama hipotermi baik pada bayi kurang bulan (51\%) maupun bayi cukup bulan $(31,1 \%)$, diikuti dengan hipoksi (36,7\%), hipoglikemi $(5,0 \%)$, dan yang cukup jarang terjadi adalah hipoperfusi $(1,4 \%)$.

\section{Pembahasan}

Pada penelitian kami terlihat jenis kelamin lakilaki lebih banyak mengalami kondisi tidak stabil.
Walaupun demikian ternyata prevalensi mengalami kondisi tidak stabil antara bayi laki-laki dan perempuan tidak berbeda bermakna.

Hipoglikemi ditemukan pada 5\% bayi yang dirujuk. Penelitian yang dilakukan oleh Najati $\mathrm{dkk}^{7}$ memperlihatkan prevalensi hipoglikemi pada bayi rujukan di RS Tabriz Alzahra, Iran 0,4\%. Hal tersebut menunjukkan bahwa kasus hipoglikemi belum banyak diketahui dan diatasi pada tempat pelayanan kesehatan tingkat pertama. Sering kasus hipoglikemi baru dipikirkan setelah timbul gejala terutama kejang. Bayi hipoglikemi pada umumnya tidak menunjukkan gejala klinik atau hanya menampilkan gejala klinik yang tidak spesifik seperti letargi, tonus yang lemah, takikardi, gangguan napas, dan hipotermi. Keterlambatan dalam tata laksana hipoglikemi dapat menyebabkan gangguan neurologik yang bermakna seperti kerusakan otak yang permanen sampai kematian. ${ }^{8,9}$

Hipotermi adalah kondisi tidak stabil yang merupakan salah satu penyebab utama kematian terutama pada BBLR. Hal tersebut menunjukkan bahwa para pelayan kesehatan belum memahami mengenai menjaga kestabilan suhu. Dalam penelitian yang dilakukan Laptook $\mathrm{dkk}^{10}$ terlihat bahwa setiap penurunan suhu tubuh $1{ }^{\circ} \mathrm{C}$ saat masuk rawat rumah sakit akan meningkatkan angka kematian 28\% dan angka kejadian sepsis awitan lambat $11 \%$.

Penelitian lain yang dilakukan Mizzi $\mathrm{dkk}^{11} \mathrm{di}$ St. Luke's Hospital, G'Mangia, Malta menunjukkan terdapat penurunan kejadian hipotermi sedang antara bayi yang dirujuk ke rumah sakit pada tahun 2002 yaitu dari $32,3 \%$ menjadi $14,4 \%$ pada tahun 2005. Sedangkan bayi yang masuk rumah sakit dengan suhu normal meningkat dari $25,5 \%$ pada tahun 2002 menjadi 43,4\% pada tahun 2005. Perbaikan klinis tersebut terjadi setelah dilakukan beberapa intervensi antara lain publikasi berbagai penelitian tentang pemantauan suhu pada perawatan bayi baru lahir, dilakukan beberapa pelatihan/ kuliah kepada para bidan, perawat dan staf medik serta perubahan kebijakan tentang penundaan waktu memandikan bayi pada hari kedua dari yang semula segera setelah lahir. Beberapa faktor lain yang berhubungan dengan penurunan kejadian hipotermi adalah inisiasi menyusu dini dan perawatan metode kanguru. ${ }^{12}$

Kondisi tidak stabil kedua tersering dijumpai adalah hipoksia (36,7\%). Hipoksia berhubungan dengan gangguan napas/respiratory distress of the 
newborn (RDN) yang merupakan alasan kedua terbanyak bayi yang dirujuk $(25,2 \%)$ setelah sepsis (29,5\%). Dalam the S.T.A.B.L.E program pun tercatat bahwa gangguan napas merupakan alasan tersering untuk merujuk pasien ke tempat pelayanan intensif, karena kejadian sepsis di negara maju telah dapat ditekan dengan tindakan pencegahan infeksi yang memadai. ${ }^{3}$

Tempat pelayanan bayi baru lahir di Makassar pada umumnya belum memiliki sarana yang memadai untuk memberi penunjang terhadap gangguan napas. Tidak ada alat pengukur saturasi (pulse oxymetri) untuk memantau pemberian oksigen yang adekuat tanpa menimbulkan efek toksik memaksa para klinisi untuk segera merujuk bayi baru lahir dengan gangguan napas terutama bayi prematur. Masalah yang dapat ditimbulkan oleh kadar oksigen dalam darah yang tidak terkontrol dengan baik, antara lain retinopay of prematurity (ROP) dan chronic lung disease (CLD)

Hipoperfusi yang dinilai berdasarkan waktu pengisian kembali kapiler terbukti tidak banyak ditemukan pada bayi-bayi yang dirujuk. Waktu pengisian kapiler yang memanjang merupakan salah satu tanda terdapat masalah sirkulasi pada bayi yang dapat dilakukan tanpa alat yang canggih. Waktu pengisian kapiler untuk bayi normal adalah 3 detik. ${ }^{6}$ Pengukuran pada telapak tangan dan tumit lebih umum dilakukan tetapi sering terdapat perbedaan hasil antar penilai. Raichur ${ }^{6}$ dan Strozik ${ }^{13}$ menambahkan hanya pengukuran di dada (sternum) memberikan hasil yang tidak berbeda bermakna antar penilai. Dalam penelitian yang dilakukan oleh Gorlick $\mathrm{dkk}^{14}$ memperlihatkan bahwa pemanjangan waktu pengisian kapiler sangat berhubungan dengan suhu ruangan oleh karena itu suhu ruangan yang dianjurkan untuk penilaian waktu pengisian kembali kapiler sebaiknya berkisar antara $26-30^{\circ} \mathrm{C}$.

Disimpulkan dari penelitian kami, sebagian besar bayi baru lahir dirujuk ke rumah sakit dalam kondisi klinis yang tidak stabil terutama akibat hipotermi, diikuti dengan hipoksia, hipoglikemi, dan hipoperfusi. Diperlukan pelatihan tenaga kesehatan dalam ketrampilan dalam melaksanakan rujukan bayi baru lahir.

\section{Daftar pustaka}

1. Departemen Kesehatan RI. Pedoman pelaksanaan program rumah sakit sayang ibu dan bayi. Jakarta; 2009.

2. Departemen Kesehatan Republik Indonesia. Sumber daya dan pelayanan perinatal dalam paket pelatihan pelayanan obstetri dan neonatal emergensi komprehensif (PONEK) asuhan neonatal esensial. Jakarta;2009.

3. Karlsen KA. Pre-transport/post-resuscitation stabilization care of sick infants guidelines for neonatal healthcare providers. Edisi ke-5. Park City: Utah; 2006. Didapat dari :URL:http://www.stable program.org.

4. Cornblath M, Hawdon JM, Williams AF, Aynsley-Green A, Ward-Platt MP, Schwartz R, Kalhan SC. Controversies regarding definition of neonatal hypoglycemia: suggested operational thresholds. Pediatrics 2000;105:1141- 5 .

5. Cinar ND, Filiz TM. Neonatal thermoregulation. Journal of Neonatal Nursing 2006;2:69-74.

6. Strozik KS, Pieper CH, Roller J. Capillary refilling time in newborn babies: normal values. Archives of Disease in Childhood 1997;76:F193-F6.

7. Najati N, Saboktakin L. Prevalence and underlying etiologies of neonatal hypoglycemia. Pakistan Journal of Biological Sciences 2010;13:753-6.

8. Beers MH., Berkow B. The merck manual of diagnosis and therapy. Edisi ke-17. New York: John Wiley and Sons; 2000

9. Dashti Nasrin, Einollahi N, Abbasi S. Neonatal hypoglycemia: prevalence and clinical manifestations in Tehran Children's Hospital. Pak J Med 2007;23:340-3.

10. Laptook AR, Salhab W, Bhaskar B. Admission temperature of low birth weight infants and associated morbidities. Pediatrics 2007;119:643-9.

11. Mizzi J, Muskat RV. Hypothermia in the early neonatal period: follow-up study. Malta med J 2007;19:34-7.

12. Mullany LC, Katz J, Khatry SK, LeClerq SC, Darmstadt GL, Tielsch JM: Risk of mortality associated with neonatal hypothermia in Southern Nepal. Arch Pediatr Adolesc Med 2010;164:650-6.

13. Raichur DV, Aralihond AP, Kasturi AV, Patil DH. Capillary refill time in term neonates: bedside assessment. Indian J Pediatr 2001;68:613-5.

14. Gorelick MH, Shaw KN, Baker MD. Effect of ambient temperature on capillary refill in healthy children. Pediatrics 1993;92;699-702. 